\title{
Sciendo
}

Administration, vol. 68, no. 4 (2020), pp. 27-40

doi: 10.2478/admin-2020-0022

\section{The role of the 'centre' in public service reform}

\author{
Muiris MacCarthaigh \\ School of History, Anthropology, Philosophy and Politics, Queen's \\ University Belfast, Northern Ireland
}

\begin{abstract}
Amongst his many interests in public administration, the practical and challenging task of implementing and evaluating public service reform has been a consistent feature of the oeuvre of research over Richard Boyle's career (cf. Boyle, 2004, 2016; Boyle \& Joyce, 1988; Boyle \& Lemaire, 1999; Boyle \& MacCarthaigh, 2011). In this article, the focus is on the role played by the 'centre' in public service reform both conceptually and in practice. The article first considers what is meant by the centre in Irish politicaladministrative life, before reflecting on how we might understand different forms of public sector reform governance and then applying them to the Irish case. The centre-led reforms that occurred between the 1960s up to the late 2000s are reviewed, before more recent efforts from 2011 up to the present are presented. A final section summarises the contribution.
\end{abstract}

Keywords: Core executive, Ireland, public sector reform, governance

\section{Introduction: Where lies the centre?}

There are two interpretations of the meaning of 'centre' in Irish government. The first may be considered as the 'core executive', a phrase first coined by Dunleavy \& Rhodes (1990) to replace the idea of cabinet government as the primary focus of analysis. In this interpretation, the centre consists of the web of institutions, 
committees, networks, and formal and informal practices that constitute the apex of governing in unitary states such as Ireland. The idea was to adopt a relational approach to the understanding of how decisions were made and resources allocated, such that no one actor could be said to have complete authority (Corbett et al., in press; Elgie, 2011; Rhodes, 1997). As well as seeking to expand the focus of what central government comprises, the study of core executives chimed with the emergence of 'governance' as a concept to capture the multi-actor and multidimensional realities of policymaking and implementation.

There remains some debate about the extent to which the idea of a core executive represents a diminution of central authority from the normative perspective of government consisting of executive authority being solely and collegially exercised by those ministers appointed by parliament. The alternative perspective is that it describes an extension of the power of some ministers, and certainly prime ministers, through enhancement of the 'reach' of those located at the very heart of government, such as ministerial advisers (Burch \& Halliday, 2004). For this reason, one of the most commonly studied features of core executives is their capacity to coordinate, including the political science focus on the ability of parties in coalition governments to work together (Bowler et al., 2016) and the more public administration concentration on the instruments of coordination (Agranoff, 2006).

In their study of how the Irish core executive managed Ireland's adaptation to European membership, Laffan \& O'Mahony (2008) adopt this perspective of the centre of Irish government. They refer to the core executive as 'the Irish government and central administration or bureaucracy' and later the 'prime minister, the government, ministries known as departments (corresponding to all main areas of policy) and the civil or administrative service'. Within this they allocate varying levels of authority and influence, depending on the policy issue at hand. The key point is that it reflects the idea of the centre being, in effect, the departmental civil service and their political masters, which form the central component of the broader Irish public service.

An alternative interpretation provided by Hardiman et al. (2010, based on Peters et al., 2000) suggested the core executive is comprised of the Department of the Taoiseach and the cabinet secretariat. This narrower frame of analysis views it as those at the pinnacle of state authority in the classical hierarchical and pyramid-like structure of the Westminster-Whitehall chain of command. From this apex position, 
policy coordination can be more easily managed given the limited range of actors and veto points in decision-making, and political signals and authority can be rapidly deployed as necessary.

For this article, the interpretation used lies between these two perspectives, and arises perhaps uniquely in the Irish context. It considers the core executive (prior to 2011) to be the two traditionally most powerful ministries in Irish government, i.e. the Departments of Finance and Taoiseach (prime minister). The Department of the Taoiseach (and its predecessor from 1922-37, the Department of the President of the Executive Council) provides a supporting role for the Taoiseach as well as coordinating the work of the cabinet of ministers which comprise the executive authority of the state. The department has held considerable agenda-setting power by virtue of the Taoiseach's constitutional right to appoint and fire ministers, and to set strategic priorities for the state, and the department's control of the cabinet agenda through which all government decisions require approval.

The Department of Finance is the only government department specifically recognised in both the 1922 and the 1937 Constitutions (Article 52 and Article 28.7, respectively), and has since its earliest days been an office of considerable authority across the entirety of the Irish public service. By virtue of its control of all revenues coming in and out of the state's coffers, it held considerable veto power over the activities of the other 'line' departments who depended on it for funding. The Minister for Finance was also the employer of all public servants in the state, and therefore the department was traditionally the lead negotiator on behalf of the state with public service unions.

Prior to the creation of a third 'central' department in 2011, no major policy issue could proceed without the support of these two departments, and normally a 'sponsoring' line department. Hence, Laffan \& O'Mahony (2008, p. 64) refer to the 'Holy Trinity' of the Departments of Taoiseach, Finance and Foreign Affairs in Europeanising Irish public policy. Similarly, major crime initiatives such as increased deployment of police or reorganisation of court jurisdictions require the policy and expenditure approvals of the Departments of Taoiseach and Finance respectively, as well as the Department of Justice.

Prior to 2011, Taoiseach and Finance were thus the main loci of authority and decision-making in Irish public governance and the origin of delegated power and authority across the Irish administrative system, including to a myriad of state agencies and bodies via their 
'parent' departments. All policy initiatives of national importance required their approval. This included the vexed issue of public service reform. Before examining this issue in more detail, some different modes of reform governance must be elaborated upon.

\section{Modes of public service reform governance}

The practice of public management reform, defined as 'deliberate changes to the structures, processes and/or cultures of public organizations to get them to run better' (Pollitt \& Bouckaert, 2017, p. 2), has attracted a wide variety of theories and analytical frameworks in academic public administration (Torfing et al., 2020). In practice, few states adopt a single reform 'model' and contingent and institutional factors come into play, as well as partisan politics. For the purposes of explanation in this paper, we may usefully draw upon the established distinction between the three dominant forms of social control - hierarchy, network and markets (Bouckaert et al., 2010; Thompson et al., 1991).

In the hierarchical mode of control, common to administrative bureaucracies, actors interact on the basis of authority and 'top-down' control, framed by means of rules and planning. This mode is characterised by chains of superior-subordinate relationships, the use of standards and routine oversight mechanisms, and uniformity of norms and values. Actors that are being controlled are considered relatively passive objects and conflicts are resolved through authority, which is exercised by the controlling government. In theory, by reducing the number of actors with veto power, a reform policy can be more efficiently pursued than one involving multiple veto players and associated potential for blockages. Top-down hierarchical methods for policy implementation can be effective and easily understood, and most administrative systems are designed using hierarchical principles. But this is not to say that there will not be resistance and strategic behaviour by those subject to hierarchical controls and methods of coordination and oversight, and there are considerable transaction costs involved in ensuring that a policy is faithfully implemented as designed.

In contrast, market governance is based on competition, bargaining and exchange between actors. The general assumption of the market approach to governance is that actors base their behaviour according to the price within a competitive market, and contractual exchange relations are based on that price. In an attempt to emulate the 
reduction of transaction costs which characterises the private sector, the price mechanism, incentives and self-interest coordinate actors through the 'invisible hand'. Thus, reform ideas are 'sold' to governments by management consultants, private sector providers and public agencies offering paid-for services, who generate efficiencies not only from up-scaling but also from competitive pressures and entrepreneurialism. Unlike the classic bureaucratic approach, there are no detailed ex ante rules set by superiors that direct implementation processes. Moreover, unlike hierarchies, in their pure form they are based on a horizontal interaction relation between equal and mutually independent actors. Oversight arrangements involve the use of extensive performance-monitoring systems and audits, as well as benchmarking and performance-based rewards and sanctions.

The final mechanism - governance through networks - involves voluntary cooperation and collaboration between actors based on increasing levels of trust and reciprocity, and is also incentive based. The network mechanism is based on the idea that actors are able to identify complementary interests, which in turn leads to resource exchanges between actors that are based on interdependent relations and loyalty (Kickert et al., 1997). There is a need for common knowledge, values and strategies between partners, and networkbased reform governance means self-recognition of potential synergies within the group, and voluntary determination of a collaborative response. Network-based approaches tend to involve more frequent and personal consultation and collaborative measures, and involve peer perspectives and user representation. All three modes have been present in Irish public service reform efforts in recent years, and in all cases the centre has played an important agenda-setting role. We consider each briefly.

\section{Hierarchical-based approaches to reform}

Public sector reform in Ireland has traditionally, though not always, been a centrally led affair. This is not a surprise given that hierarchical approaches are the traditional means of addressing problems of coordination by offering clear chains of command and levels of authority. In a discussion paper for the Committee for Public Management Research on The Role of the Centre in Promoting Civil Service Modernisation, Boyle (2004) argued that as it occupied the position of most authority, the centre performed three important functions in this endeavour: firstly, leading modernisation through agenda management, intervention management, knowledge and 
practice sharing, obstacle removal and connections to the political process; secondly, reviewing modernisation through challenging other departments, coordinating reporting arrangements, examining implementation problems and engaging political fora such as parliamentary committees; finally, by participating in modernisation and opening itself to the same scrutiny it expects of others, the centre can ensure it is playing a positive role and adding value to the process.

However, centre-led reform efforts adopting hierarchical approaches run several risks. In the first instance hierarchies are slow to respond to changing circumstance and often inflexible in the face of complexity. Communications may also be problematic as signals from the top may be misinterpreted or reinterpreted as they move through the levels. This leads to the age-old dilemma of ensuring that policies conceived at the centre are faithfully implemented in the field. Concern about the mismatch between the ideas set at the 'top' and their practical feasibility at the 'bottom' or 'frontline' has spawned a huge body of research on implementation since Pressman \& Wildavsky's (1973) seminal work. It has also been the source of interest for the work of Lipsky's (1980) street-level bureaucrats, and how they juggle competing reform demands. Even with the best of efforts, rank-and-file bureaucrats may not be aware of the reform efforts which are designed to change how they work.

Take, for example, the results of two civil service employee engagement surveys from 2015 and 2017, which provide excellent windows into how staff consider their work and level of empowerment. These followed some of the most extensive reforms in the history of the state, necessitated by the financial crisis (MacCarthaigh, 2017). In both surveys, one of the lowest scores was in respect of the 'involvement climate', interpreted as 'the extent to which civil servants feel that they are involved openly in decision making in their organisation' (Government of Ireland, 2017). Only 36 per cent of respondents felt they were involved in organisational decision-making in 2015, and 38 per cent in 2017.

Centrally devised reforms may also be poorly designed and fail to appreciate local circumstances and contexts. The expected causeeffect design may be flawed or the necessary structures and resources to ensure implementation may not be in place or available at all. Reforms that do not at some stage involve those likely to be most affected by them are less likely to be embraced, and recent work demonstrates that successive bouts of reform can in fact dampen innovation (Wynen et al., 2019). 


\section{Network-based approaches to reform}

Prior to the financial crisis, network approaches to public service reform had been actively pursued, most explicitly through negotiations between government and public service unions as part of the corporatist 'social partnership' process. Social partnership comprised triennial pay and tax agreements which commenced in 1987 and involved trade unions, business organisations, the agri-food sector and later civil society associations in what Hardiman (2006) referred to as 'flexible network governance'. And although a new agreement was signed off in 2006 encompassing a wide variety of policy issues beyond solely pay and tax issues, the process was effectively abandoned with the onset of the financial crisis in 2008.

At an organisational level, ministerial departments, state agencies, local authorities and other forms of public sector organisation attempted to replicate this model of problem-solving and mutual agreement on reform through internal workplace 'partnerships'. These forums offered unionised and non-unionised interests to engage with management in an attempt to overcome traditional superior-subordinate methods of operating. They were also supported by substantial pay increases in the early 2000s and the introduction of performance-related pay at the national and local government levels. At the national level, however, the 'shadow of hierarchy' remained present throughout and the rapid end of partnership in 2008 brought to an abrupt end several years of network-based approaches to reform.

\section{Market-based approaches to reform}

The Irish experience of market-based reform needs to be considered at two levels. At an organisational level, the public service has routinely engaged consultants and other external parties in reform and modernisation initiatives, akin to what might be found in the private sector. For the most part this is uncontroversial, and the development of procurement, legal and contracting skills within the public service has been a feature, particularly in an EU context and in respect of major infrastructure projects. However, many projects that have been the source of major cost overruns have tended to involve such external parties (Office of the Comptroller and Auditor General, 2005).

At a more system-wide level, Ireland has engaged to varying degrees with market-inspired 'New Public Management' (NPM) reforms since the mid 1990s. Although a loosely defined term designed to capture a number of broadly similar administrative doctrines' (Hood, 1991, p. 3), at its heart NPM was about introducing 
private sector ideas around performance and efficiency into the public sector. Despite the open nature of the Irish economy to market forces, what might be seen as the more totemic elements of NPM, such as contract-based employment, decentralisation of authority, and fluid public-private labour markets, did not materialise.

A review by the OECD of the Irish public service, published in 2008, suggested that since the early 1990s, Ireland had 'significantly advanced along a "New Public Management" continuum' (OECD, 2008, p. 18). Global NPM principles had certainly featured in reform proposals and political rhetoric, but those changes that had occurred (most notably the explosion in the state agency population) had weak connection to NPM's efficiency and market-based objectives; rather, relatively uncontroversial ideas around performance measurement, citizen-centred services and strategic planning modernisation programmes appeared within the public service. And so despite its geographical proximity to a leading NPM-reformer (the UK), on close examination Ireland was something of a laggard in respect of NPM (Hardiman \& MacCarthaigh, 2011).

\section{Management of public service reform by the centre}

Public service reform was not an issue of concern to Irish governments prior to the $1960 \mathrm{~s}$ - the idea of reform being confined to matters of pay and terms and conditions of employment. However, in common with developments elsewhere, by the late 1960s pressure grew within the civil service to improve policy development capacity as distinct from simply implementing ministerial demands. A Public Services Organisation Review Group was established in 1966, under the chairmanship of Liam Devlin, to 'examine and report on the organisation of the Departments of State... including the appropriate distribution of functions as between both Departments themselves and Departments and other bodies' (Public Services Organisation Review Group, 1969, p. 3). Its recommendations led to the establishment of a new department to focus on the work of the public service. The Department of the Public Service was created in 1973 but otherwise the thrust of the Review Group's work was muted by industrial relations issues. The Department of the Public Service was eventually reabsorbed into the Department of Finance in 1987, though it retained a distinctive identity within it (Ward, 2018).

From then until 2011 responsibility for public service reform had effectively been split between the Departments of the Taoiseach and 
Finance, with a small Public Service Modernisation team seeking to establish reform initiatives but the Public Service Management Development Division of the Department of Finance having considerable veto power over what reforms it would support. This included a wide range of initiatives which flowed from Ireland's answer to NPM, the Strategic Management Initiative (SMI). The SMI provides the framework for a range of modernisation and reform initiatives, including a Quality Customer Service Initiative, a (financial) Management Information Framework and a Performance Management and Development System.

New legislation provided for strategy statements to be produced by departments every three years, or within six months of a new minister's appointment, as well as annual reports by departments, first published in 1999. Many of these reforms are now embedded across the Irish public service, but maintaining political interest in managerial reforms remained problematic. Enthusiasm waned further into the early 2000s as the economy soared and the numbers employed across the public service swelled. Reform also became increasingly connected to pay negotiations with public service unions. An OECD review designed to spark a new era of reform was commissioned by the government in 2006 and eventually published in 2008, but was almost instantly shelved as the economy imploded in 2008 due to the financial crisis. However, the consequences of this crisis were to be the most centrally managed and wide-ranging reforms of the Irish civil and public service in its history.

\section{Reforming the centre in Irish political-administrative governance}

This Taoiseach-Finance duopoly at the heart of Irish government was transformed following the 'earthquake' general election of 2011 and the ascent to national office of a coalition government holding the largest parliamentary majority ever held by a new administration. One of the first acts of the incoming Taoiseach, Enda Kenny, TD, was to create a new and powerful department at the heart of government. MacCarthaigh (2017) records the political reasons for the creation of the Department of Public Expenditure and Reform (DPER) but the main consequence was to add a third powerful actor to the centre of Irish government.

The expenditure side of the Department of Finance was removed, along with public sector industrial relations, and joined with the small 
Public Service Modernisation Division, which had been removed from the Department of the Taoiseach, to form the new department. The creation of DPER broke up the decades-old duopoly at the heart of Irish government between the Departments of Finance and Taoiseach. It shared its premises with the Department of Finance, allowing for strong coordination between the two departments, including regular face-to-face communication between the two ministers, both senior figures in the respective coalition parties.

As well as enforcing strict spending controls across every public service organisation, DPER negotiated two very significant pay deals which resulted in fundamental changes to public service employment. And at the same time it introduced a suite of political and administrative reforms, many of which had evaded previous Irish governments, through a new Reform and Delivery Office (RDO). The RDO established centralised mechanisms to carry out its work, including an online 'reform office portal' to provide direct communications between the office and the broader administrative system, as well as real-time reports on reform implementation progress across the bureaucracy. Some, but not all, of these reforms were mandated under the loan programme agreed with the troika of the European Commission, European Central Bank and International Monetary Fund (MacCarthaigh \& Hardiman, 2020). But the architecture created at the heart of government to manage the macroeconomic aspects of the loan programme - including a powerful sub-unit of the cabinet known as the Economic Management Council - also proved useful for oversight of reform implementation.

Combining a detailed reform agenda to a centralised budgetary system was also very effective in ensuring implementation. And with public service unions also acceding to the reforms in return for avoiding redundancy measures, DPER was successfully able to introduce more reforms to a wider range of issues than any previous department had done. This included fundamental changes to the public service labour market, terms and conditions of public service employment, organisational mergers, and rationalisation of procurement and administrative support functions via new shared service centres.

Maintaining a focus on reform implementation and efficiency became a greater challenge as the financial crisis receded in 2014. Public service unions sought to reverse the cuts of the post-2008 crisis period in an accelerated fashion and DPER sought to achieve more engagement from the various sectors of the bureaucracy in a new 
public service reform effort. After the general election in 2016, DPER was retained as a department but shared a single minister with the Department of Finance. A new reform plan - Our Public Service 2020 - was launched in 2017. In tone and content it was more redolent of the pre-crisis reform culture, seeking a more network-based approach to reform across the public service, involving ideas around shared leadership, innovation and collaboration. The strategy was overseen by a new Public Service Leadership Board, comprised of representatives from across the service and chaired by the secretary general of DPER. The new government which took office in June 2020 did so in the midst of the Covid-19 pandemic, and public service reform moved down the political agenda as efforts were made to manage the new crisis.

\section{Conclusions}

Although by no means an international leader in public service reform, the demand for such reforms has increased in Ireland since the 1970s and with varying levels of success. Although we can find evidence of market and network-based approaches to these reform efforts, such is the organisation of Irish political-administrative governance that hierarchical approaches have tended to dominate. This is particularly the case in the post-2011 period when public service reform became an integral part of the response to the economic crisis.

In contrast to the $1980 \mathrm{~s}$, when deregulation and decentralisation were to the fore in public service reforms arising from crisis, the more recent financial crisis resulted in quite extensive recentralisation of public authority and re-regulation of the public sector (Randma-Liiv \& Kickert, 2017, p. 14). These more recent measures included tightening of financial controls, agency rationalisations and mergers of organisational 'back office' functions to provide more standardised support services across the public sector. Ireland provided a particularly prominent example of this, and the manner in which DPER deployed its authority and financial resources resulted in an unprecedented range of reforms across the Irish public service during 2011-16. As the economic crisis waned, it became more difficult to maintain the urgency around reform, but DPER's success in managing significant expenditure cutbacks has resulted in its ongoing existence.

At time of writing, 'the centre' of Irish government remains the three core departments of Taoiseach, Finance and Public Expenditure 
and Reform, each with a significant veto over the others. Having originally been created for the term of a single administration between 2011 and 2016, DPER is (since June 2020) part of a third administration, and with increased institutionalisation and embedded organisational identity at the heart of the Irish bureaucratic system. Informal as well as formal networks operate to make sure the departments at the centre function in delivering on the government's policy agenda, but outside of the centre hierarchical modes of governance underpin the system of implementation.

As a small, unitary state, Ireland will continue to have the centre as the primary source of reform legitimation and resources, and the legacies of the past suggest that hierarchical approaches will be the default for organising reform efforts. However, market and network perspectives on reform continue to offer means of conceptualising alternatives to this. Critical analysis and evaluation play an important role in this work and in determining how best the centre can achieve successful reform. In this regard, Boyle's conclusions from the turn of the century remain particularly pertinent:

Civil service modernisation is a continual and evolving process. Given the disparate nature of the centre, determining the most effective role for the centre is no easy task. Confronting and questioning the part played by the centre in modernisation, as leader, reviewer and participant, requires a combination of critical self-scrutiny and external assessment. (Boyle, 2004, p. 50)

\section{References}

Agranoff, R. (2006). Inside collaborative networks: Ten lessons for public managers. Public Administration Review, 66, 56-65.

Bouckaert, G., Peters, B. G., \& Verhoest, K. (2010). The coordination of public sector organizations: Shifting patterns of public management. Basingstoke: Palgrave Macmillan.

Bowler, S., Bräuninger, T., Debus, M., \& Indridason, I. H. (2016). Let's just agree to disagree: Dispute resolution mechanisms in coalition agreements. Journal of Politics, 78 (4), 1264-78.

Boyle, R. (2004). The role of the centre in promoting civil service modernisation [CPMR discussion paper no. 27]. Dublin: Institute of Public Administration.

Boyle, R. (2016). Public service reform. In W. K. Roche, P. J. O'Connell \& A. Prothero (Eds), Austerity and recovery in Ireland: Europe's poster child and the great recession (pp. 214-31). Oxford: Oxford University Press. 
Boyle, R., \& Joyce, L. (1988). Making change work: Student of organisational change in Irish civil service. Dublin: Institute of Public Administration.

Boyle, R., \& Lemaire, D. (Eds) (1999). Building effective evaluation capacity: Lessons from practice. London: Transaction Publishers.

Boyle, R., \& MacCarthaigh, M. (2011). Fit for purpose? Challenges for Irish public administration and priorities for public service reform [State of the public service series no. 4]. Dublin: Institute of Public Administration.

Burch, M., \& Holliday, I. (2004). The Blair government and the core executive. Government and Opposition, 39 (1), 1-21. doi:10.1111/j.0017257x.2004.00029.x

Corbett, J., Veenendaal, W., \& Connell, J. (in press). The core executive and small states: Is coordination the primary challenge? Public Administration. https://doi.org/10.1111/padm.12682

Department of Public Expenditure and Reform. (2017). Our public service 2020. Dublin: Department of Public Expenditure and Reform.

Dunleavy, P., \& Rhodes, R. (1990). Core executive studies in Britain. Public Administration, 68 (1), 3-28.

Elgie, R. (2011). Core executive studies two decades on. Public Administration, 89 (1), 64-77.

Government of Ireland. (2017). Civil service employee engagement survey. Dublin: Department of Public Expenditure and Reform.

Hardiman, N. (2006) Politics and social partnership: Flexible network governance. Economic and Social Review, 37 (3), 347-74.

Hardiman, N., \& MacCarthaigh, M. (2011). The unpolitics of new public management in Ireland. In J. M. Eymeri-Douzans \& J. Pierre (Eds), Administrative reforms and democratic governance (pp. 55-67). London: Routledge.

Hardiman, N., Regan, A., \& Shayne, M. (2010) The core executive: The Department of the Taoiseach and the challenge of policy coordination. In E. O'Malley \& M. MacCarthaigh (Eds), Governing Ireland: From cabinet governance to delegated governance (pp. 106-27). Dublin: Institute of Public Administration.

Hood, C. (1991). A public management for all seasons? Public Administration, 69 (1), 3-19.

Kickert, W. J. M., Klijn, E. H., \& Koppenjan, J. F. M. (Eds) (1997). Managing complex networks. London: Sage.

Laffan, B., \& O'Mahoney, J. (2008). Ireland and the European Union. Basingstoke: Palgrave Macmillan.

Lipsky, M. (1980). Street-level bureaucracy. Dilemmas of the individual in public services. New York: Russell Sage Foundation.

MacCarthaigh, M. (2017). Public sector reform in Ireland: Countering crisis. Basingstoke: Palgrave.

MacCarthaigh, M., \& Hardiman, N. (2020). Exploiting conditionality: EU and international actors and post-NPM reform in Ireland. Public Policy and Administration, 35 (2), 179-200. doi:10.1177/0952076718796548 
OECD. (2008). Ireland: Towards an integrated public service. Paris: OECD.

Office of the Comptroller and Auditor General. (2005). Special report 51 Development of human resource management system for the health service. Dublin: Office of the Comptroller and Auditor General.

Peters B. G., Rhodes R. A. W., \& Wright V. (2000). Staffing the summit - The administration of the core executive: Convergent trends and national specificities. In B. G. Peters, R. A. W. Rhodes, \& V. Wright (Eds), Administering the summit. Transforming government (pp. 3-24). London: Palgrave Macmillan.

Pollitt, C., \& Bouckaert, C. (2017). Public management Reform: A comparative analysis - Into the age of austerity. Oxford: Oxford University Press.

Pressman, J. L., \& Wildavsky, A. B. (1973). Implementation: How great expectations in Washington are dashed in Oakland. Berkeley, CA: University of California Press.

Public Services Organisation Review Group. (1969). Report of the Public Services Organisation Review Group [The Devlin report]. Dublin: The Stationery Office.

Randma-Liiv, T., \& Kickert, W. (2017). The impact of the fiscal crisis on public administration reforms: Comparison of 14 European countries. Journal of Comparative Policy Analysis: Research and Practice, 19 (2), 15572. doi: 10.1080/13876988.2015.1129737

Rhodes, R. (1997). Understanding governance: Policy networks, governance, reflexivity and accountability. Milton Keynes: Open University Press.

Thompson, G., Frances, J., Levačić, R., \& Mitchell, J. (1991). Markets, hierarchies \& networks: The coordination of social life. London: Sage.

Torfing, J., Andersen, L. B., Greve, C., \& Klausen, K. K. (2020). Public governance paradigms: Competing and co-existing. Cheltenham: Edward Elgar.

Ward, T. (2018). Critical junctures and the Department of Finance: From DPS to DPER? Irish Political Studies, 33 (1): 68-87. doi: 10.1080/07907184.2017.1281251

Wynen, J., Verhoest, K., \& Kleizen, B. (2019). Are public organizations suffering from repetitive change injury? A panel study of the damaging effect of intense reform sequences. Governance, 32 (4), 695-713. https://doi.org/10.1111/gove.12404 